ISSN 1392-3196 / e-ISSN 2335-8947

Zemdirbyste-Agriculture, vol. 107, No. 1 (2020), p. 79-86

DOI 10.13080/z-a.2020.107.011

\title{
Expression of pathogenicity and virulence related genes in Pseudomonas syringae pv. syringae under copper stress
}

\author{
Yalda VASEBI ${ }^{1}$, Reza KHAKVAR ${ }^{1}$, Mohammad Mehdi FAGHIHI ${ }^{2}$, \\ Boris Alexander VINATZER ${ }^{3}$ \\ ${ }^{1}$ University of Tabriz, Faculty of Agriculture \\ Tabriz, Iran \\ E-mail: yalda vasebi@yahoo.com \\ ${ }^{2}$ Agricultural Research Education and Extension Organization (AREEO), \\ Hormozgan Agricultural and Natural Resources Research and Education Center \\ Bandar Abbas, Iran \\ ${ }^{3}$ Virginia Polytechnic Institute and State University, \\ Virginia Tech School of Plant and Environmental Sciences \\ Blacksburg, VA 24061, USA
}

\begin{abstract}
Stone fruit bacterial canker is one of the most destructive diseases of apricot in Iran. Copper-based compounds are widely used to protect plants against bacterial diseases, but pathogens frequently evolve resistance against copper $(\mathrm{Cu})$. This study was conducted to investigate the genetic diversity of the $\mathrm{Cu}$ resistance gene copA among strains of the causal agent of canker disease of stone fruits Pseudomonas syringae pv. syringae (Pss), isolated from apricot trees in East Azarbaijan province of Iran. The phylogenic trees based on copA and rpoD are very similar to each other revealing no evidence of recombination. To test the hypothesis that pathogenicity- and virulencerelated genes may be induced by $\mathrm{Cu}$ in Pss strains, quantitative real-time polymerase chain reaction (qRT-PCR) was used to evaluate the expression of genes $\operatorname{alg} \mathrm{D}, \operatorname{cop} \mathrm{A}, f i \mathrm{C}, h r p \mathrm{~A}, \operatorname{syr} \mathrm{B}$ and $t a t \mathrm{C}$, in the $\mathrm{Cu}$ sensitive Pss 170 strain upon exposure to $\mathrm{Cu}$. Among the tested genes, the $\operatorname{alg\mathrm {D}}$ and $\operatorname{cop} \mathrm{A}$ involved in alginate synthesis and $\mathrm{Cu}$ resistance, respectively, showed the highest increase in expression compared to a non-copper (control): 4.75-fold and 2.68-fold, respectively. Based on these results and on the conservation of genes algD and copA in Pseudomonas pathovars, antimicrobials that target $\mathrm{AlgD}$ and CopA proteins should be developed to use in combination with $\mathrm{Cu}$ to increase control efficiency.
\end{abstract}

Key words: $\operatorname{alg\mathrm {D}}$ gene, $\operatorname{cop} \mathrm{A}$ gene, gene expression, real-time $\mathrm{PCR}$, stone fruit canker.

\section{Introduction}

Pseudomonas syringae strains have been isolated from over 180 plant species (Kennelly et al., 2007). P. syringae strains are assigned to more than 50 different pathovars based on host range and 13 phylogroups based on phylogeny (Berge et al., 2014). P. syringae pv. syringae (Pss) van Hall is one of the most destructive causal agents of canker diseases on stone fruit trees. The disease causes yield reductions of up to $80 \%$ (Kennelly et al., 2007). In Iran, the disease is currently found in most stone fruit orchards in the country (Najafi Pour Haghighi, Taghavi, 2014).

Copper-based compounds have been widely used for management of bacterial diseases caused by Pseudomonas spp., including canker disease of stone fruits (Wimalajeewa et al., 1991). Copper homeostasis systems act as $\mathrm{Cu}$ resistance mechanisms and are based on intracellular and extracellular sequestration, enzymatic detoxification, reduced $\mathrm{Cu}$ transportation, enhanced efflux of cupric ions, or $\mathrm{Cu}$ complexation by cell components (Rademacher, Masepohl, 2012). Essential Cu metabolism-related genes that aid in $\mathrm{Cu}$ detoxification are usually located on the main chromosome (Hwang et al., 2005). Copper resistance genes instead can be located either on the main chromosome or on plasmids. Plasmiddetermined $\mathrm{Cu}$ resistance has been found in diverse Gram-negative bacterial species, such as P. syringae, Xanthomonas campestris and Escherichia coli. In $P$. syringae, plasmid-encoded $\mathrm{Cu}$ resistance genes have been identified in various pathovars (Cazorla et al., 2002).

$P$. syringae pv. tomato DC3000 was the first intensively-studied $\mathrm{Cu}$ resistant plant pathogenic bacterial strain (Cervantes, Gutierrez-Corona, 1994). In this strain, $\mathrm{Cu}$ resistance is encoded by the plasmid pPT23D, which is highly conserved among $P$. syringae strains including strains of Pss (Scheck et al., 1996). This plasmid contains a Cu-resistance operon (copABCDRS) regulated by a $\mathrm{Cu}$-inducible promoter. Four genes $(\operatorname{cop} \mathrm{A}, \operatorname{cop} \mathrm{B}, \operatorname{cop} \mathrm{C}$ and $c o p \mathrm{D}$ ) encode structural components and two genes $(c o p R$ and $c o p S)$ have regulatory functions (Mills et al., 1993). CopA and CopB act as efflux ATPase, while CopC

Please use the following format when citing the article:

Vasebi Y., Khakvar R., Faghihi M. M., Vinatzer B. A. 2020. Expression of pathogenicity and virulence related genes in Pseudomonas syringae pv. syringae under copper stress. Zemdirbyste-Agriculture, 107 (1): 79-86. DOI 10.13080/z-a.2020.107.0011 
and $C o p D$ are responsible for $\mathrm{Cu}$ uptake (Rademacher, Masepohl, 2012).

Exposure to $\mathrm{Cu}$ may affect expression of pathogenicity and virulence genes that encode toxins, such as syringomycin (Scholz-Schroeder et al., 2001). Other virulence genes encode effector proteins that are translocated into plants by the type III secretion system (T3SS), which is encoded by hrp genes (Hwang et al., 2005; Ichinose et al., 2013). The hrp genes include hrpA, which encodes HrpA, the building block of the translocation pilus (Preston et al., 1995). P. syringae strains also produce two exopolysaccharides: alginate and levan (Laue et al., 2006). The algD is the first gene in the alginate biosynthetic gene cluster in P. syringae (Peñaloza-Vázquez et al., 1997). Copper has been found to trigger alginate gene expression in Pss (Kidambi et al., 1995). In fact, alginate can sequestrate $\mathrm{Cu}$ ions using electrostatic interactions and keep them trapped outside the cell (González et al., 2010). The twin-arginine translocation (Tat) system also contributes to virulence and pathogenicity (Bronstein et al., 2005). The tat operon comprises the tat $\mathrm{ABC}$ genes. TatC is the most conserved of the Tat proteins and acts as an initial receptor for substrate proteins (Alami et al., 2003). Bronstein et al. (2005) reported that a tatC gene mutant of DC3000 strain showed sensitivity to $\mathrm{Cu}$ and had attenuated virulence. In strain DC3000, the protein CopA has been identified as substrate of a Tat system, which is transported to the periplasm in a Tat-dependent manner (Bronstein et al., 2005). Finally, the bacterial flagellum mediates adherence, which is another important virulence trait in host colonization and flagellin monomers encoded by the $f i C$ gene (Rossez et al., 2015) are important inducers of plant defence responses (Haiko, Westerlund-Wikström, 2013).

The purpose of this study was the investigation of genetic diversity and phylogenetic relationships among Pseudomonas syringae pv. syringae (Pss) strains using the $r p o \mathrm{D}$ housekeeping gene as well as the $\mathrm{Cu}$ resistance copA gene. Also, the effect of $\mathrm{Cu}$ on the expression of a selection of the pathogenicity and virulence-related genes: $\operatorname{alg} \mathrm{D}, \operatorname{cop} \mathrm{A}, f l i \mathrm{C}, h r p \mathrm{~A}, \operatorname{syr} \mathrm{B}$ and $t a t \mathrm{C}$, was determined in a $\mathrm{Cu}$ sensitive Pss strain, which had been identified as a causal agent of canker disease of apricot.

\section{Materials and methods}

Isolation and characterization of bacterial strains. Bacterial strains were isolated from apricot trees in East Azarbaijan province, Iran, in March and April 2015. Tissues that appeared infected, including buds, blossoms, twigs and branches, were selected for isolation. To isolate bacterial strains epiphytically and endophytically, $5 \mathrm{~g}$ of crushed tissues were suspended in $20 \mathrm{ml}$ of $0.1 \mathrm{M}$ potassium phosphate buffer and 0.01 $\mathrm{M} \mathrm{Mg}$ buffer for 10 and $120 \mathrm{~min}$, respectively, on a shaker at $150 \mathrm{rpm} .100 \mu \mathrm{l}$ of suspension was streaked on nutrient agar (NA) medium (Merck, Germany) and King's medium B agar (Biolife, Italy), amended with cyclohexamide (KBC) and incubated at $25^{\circ} \mathrm{C}$ for three days. Then, morphologically different bacterial colonies were classified using Gram staining and fluorescent production on KB (King's B) medium. For identification of $P$. syringae pv. syringae (Pss) strains, purified Gramnegative fluorescent colonies were analysed using levan production, oxidase reaction, pectolytic activity on potato slices, arginine dihydrolase activity and hypersensitivity reaction on tobacco leaves (LOPAT test) as well as gelatin liquefaction, aesculin hydrolysis, tyrosinase activity and tartrate utilization (GATTa test) (Schaad et al., 2001). Syringomycin production and ice nucleation activity were tested according to Schaad et al. (2001).

Pathogenicity test. Twenty-four hours old culture of bacterial strains with a concentration of $10^{7}$ colony forming unit (CFU) $\mathrm{ml}^{-1}$ and sterile double distilled water (DDW) were used in pathogenicity test as positive and negative controls, respectively, on oneyear-old apricot twigs. Twigs in leaf germination sites were inoculated with $1 \mathrm{ml}$ of bacterial suspension and then maintained in high moisture conditions at $28^{\circ} \mathrm{C}$ for 14 days. The presence of necrotic lesions was considered an indication of pathogenicity (Mohammadi et al., 2001). Copper (Cu) resistance and growth curves. Mannitol-glutamic yeast (MGY) extract agar is a standard medium used to evaluate $\mathrm{Cu}$ resistance in vitro. Overnight cultures of each strain on NA medium were suspended in DDW (optical density $($ OD600) $=0.5)$. Ten $\mu$ l of bacterial suspensions in duplicate were spotted on MGY agar supplemented with filter-sterilized $(0.45 \mu \mathrm{m})$ stock solutions of $\mathrm{Cu}$ (II) sulphate pentahydrate (Merck Millipore, Germany) at 19 concentrations: 0, 0.05, 0.10, $0.15,0.20,0.25,0.30,0.35,0.40,0.45,0.50,0.75,1.0,1.5$, $2,2.5,3.0,3.5$ and $4.0 \mathrm{mM}$. The plates were incubated at $28^{\circ} \mathrm{C}$ for $72 \mathrm{~h}$. Each assay was performed in triplicate. The minimum inhibitory concentration of copper (MIC$\mathrm{Cu}$ ) was defined as the lowest concentration of $\mathrm{Cu}$, at which no growth was observed following incubation at $28^{\circ} \mathrm{C}$. Strains with MICs less than $0.75 \mathrm{mM} \mathrm{CuSO}_{4}$ were scored as $\mathrm{Cu}$ sensitive (Cazorla et al., 2002).

Growth of Pseudomonas syringae pv. syringae 170 strain was monitored under $\mathrm{Cu}$ conditions using MGY broth medium. The experiments were performed in $250 \mathrm{ml}$ Erlenmeyer flasks containing $70 \mathrm{ml}$ MGY broth medium with three concentrations of copper sulphate $\left(\mathrm{CuSO}_{4}\right): 0$, 0.50 and $0.75 \mathrm{mM}$. Ten $\mu$ l of bacterial grown $(\mathrm{OD} 600)=0.6)$ on nutrient broth (NB) medium (Merck, Germany) were added to the flasks. The flasks were incubated at $28^{\circ} \mathrm{C}$ with shaking at $150 \mathrm{rpm}$. Bacterial growth was monitored by measuring the optical densities of bacterial cultures using a spectrophotometer (Eppendorf, Germany) at $600 \mathrm{~nm}$ sampling every hour for $196 \mathrm{~h}$.

Detection of genes in Pss strains. CTAB (cetyltrimethylammonium bromide) method according to Doyle and Doyle (1990) with minor modifications was used for total DNA extraction and purification of bacterial strains. A NanoDrop Nano-200 (Allsheng, China) and gel electrophoresis were used for determining of concentration and quality of DNA. The primer pair rpoD-Fp/rpoD-Rp was used to amplify a fragment of the housekeeping gene rpoD (Sarkar, Guttman, 2004). The primer pair B1/B2 (Sorensen et al., 1998) was used to amplify a fragment of the syringomycin synthesis gene syr $B$. The custom-designed primers PsscopAF/PsscopAR and PsscopBF/PsscopBR were provided by Macrogen Inc. (South Korea) and were used to amplify fragments of internal regions of the $\mathrm{Cu}$ resistance genes copA and $\operatorname{cop} \mathrm{B}$, respectively. Properties of primers and DNA amplification conditions are summarized in Table 1. All polymerase chain reaction (PCR) assays were performed using a thermocycler Nano-200 (Peqlab Biotechnologie $\mathrm{GmbH}$, Germany) in a final volume of $25 \mu \mathrm{L}$ containing $12.5 \mu \mathrm{L}$ of $2 \times$ Master Mix Red (Ampliqon, Denmark), $10 \mathrm{pmol}$ of each primer for the respective gene, $8.4 \mu \mathrm{L}$ $\mathrm{H}_{2} \mathrm{O}$ and $2 \mu \mathrm{L}$ of template DNA.

Sequence alignment and phylogenic analysis. PCR products of the rpoD and copA genes were sequenced in both directions (Macrogen Inc.). The program FinchTV, version 1.4.0 (Geospiza Inc., USA) was used to check the quality of raw sequencing reads. Then, software SeqMan ${ }^{T M}$ II (DNASTAR Inc., USA) was used for editing and trimming of raw sequencing data. Obtained sequences were used to search the NCBI database (www://ncbi.nlm.nih.gov) using the BLASTN (megablast) tool. The MUSCLE algorithm implemented in the software $M E G A$, version 6 (Tamura et al., 2013) was used for sequence aligning. Sequences were aligned using the MUSCLE algorithm implemented in the software MEGA 6 (Tamura et al., 2013).

Phylogenetic trees were constructed using software Mesquite, version 2.75 (Maddison, Maddison, 2011). Phylogenic analysis was performed using program 
Table 1. Gene fragments, primers and polymerase chain reaction (PCR) conditions used in this study

\begin{tabular}{|c|c|c|c|c|c|}
\hline $\begin{array}{c}\text { Target } \\
\text { gene }\end{array}$ & $\begin{array}{c}\text { Primer } \\
\text { name }\end{array}$ & Primer sequence $5^{\prime}$ to $3^{\prime}$ & PCR conditions & $\begin{array}{c}\text { Amplicon } \\
\text { size (bp) }\end{array}$ & Reference \\
\hline rpoD & $\begin{array}{l}\text { rpoD-Fp } \\
\text { rpoD-Rp }\end{array}$ & $\begin{array}{l}\text { AAGGCGARATCGAAATCGCCAAGCG } \\
\text { GGAACWKGCGCAGGAAGTCGGCACG }\end{array}$ & $\begin{array}{l}95^{\circ} \mathrm{C} 5 \mathrm{~min} ; 30 \text { cycles } \\
\left(94^{\circ} \mathrm{C} 1.5 \mathrm{~min}, 63^{\circ} \mathrm{C} 1 \mathrm{~min} \text { and }\right. \\
\left.72^{\circ} \mathrm{C} 2 \mathrm{~min}\right) ; 72^{\circ} \mathrm{C} 10 \mathrm{~min} .\end{array}$ & 532 & $\begin{array}{l}\text { Sarkar, } \\
\text { Guttman, } \\
2004\end{array}$ \\
\hline syr B & $\begin{array}{l}\mathrm{B} 1 \\
\mathrm{~B} 2\end{array}$ & $\begin{array}{l}\text { CTTTCCGTGGTCTTGATGAGG } \\
\text { TCGATTTTGCCGTGATGAGTC }\end{array}$ & $\begin{array}{l}94^{\circ} \mathrm{C} 4 \mathrm{~min} ; 35 \text { cycles } \\
\left(94^{\circ} \mathrm{C} 1.5 \mathrm{~min}, 60^{\circ} \mathrm{C} 1.5 \mathrm{~min}\right. \\
\left.\text { and } 72^{\circ} \mathrm{C} 3 \mathrm{~min}\right) ; 72^{\circ} \mathrm{C} 10 \mathrm{~min} .\end{array}$ & 752 & $\begin{array}{l}\text { Sorensen } \\
\text { et al., } \\
1998\end{array}$ \\
\hline $\operatorname{cop} \mathrm{A}$ & $\begin{array}{l}\text { PsscopAF } \\
\text { PsscopAR }\end{array}$ & $\begin{array}{l}\text { CCTGCCATACCCATATCATCC } \\
\text { CTAGTGATCGACGCGAAAGAG }\end{array}$ & $\begin{array}{l}95^{\circ} \mathrm{C} 5 \mathrm{~min} ; 35 \text { cycles } \\
\left(94^{\circ} \mathrm{C} 90 \mathrm{~s}, 55^{\circ} \mathrm{C} 60 \mathrm{~s} \text { and }\right. \\
\left.72^{\circ} \mathrm{C} 2 \mathrm{~min}\right) ; 72^{\circ} \mathrm{C} 10 \mathrm{~min} .\end{array}$ & 650 & This study \\
\hline $\operatorname{cop} \mathrm{B}$ & $\begin{array}{l}\text { PsscopBF } \\
\text { PsscopBR }\end{array}$ & $\begin{array}{l}\text { CTGGGTGTCTTCGTCGTCTT } \\
\text { GCTGGATTGGCGGAGATA }\end{array}$ & $\begin{array}{l}95^{\circ} \mathrm{C} 5 \mathrm{~min} ; 35 \text { cycles } \\
\left(94^{\circ} \mathrm{C} 90 \mathrm{~s}, 55^{\circ} \mathrm{C} 60 \mathrm{~s} \text { and }\right. \\
\left.72^{\circ} \mathrm{C} 2 \mathrm{~min}\right) ; 72^{\circ} \mathrm{C} 10 \mathrm{~min} .\end{array}$ & 506 & This study \\
\hline
\end{tabular}

MrBayes, version 3.2.2 using a Markov Chain Monte Carlo (MCMC) algorithm (Ronquist et al., 2012) with $100,000,000$ generations, average standard deviation of split frequencies value of 0.01 , sampling every 1000 generations, and setting of the heating parameter to 0.15 . After discarding the first $25 \%$ of the generations as "burnin", the posterior probabilities were calculated from the remaining trees. The Akaike information criterion (AIC) implemented in program MrModeltest, version 2.3 (Nylander, 2004) was used to select the best model of nucleotide substitution independently for each locus. The program FigTree, version 1.4.2 (http://tree.bio.ed.ac.uk/ software/figtree) was used to visualize the trees.

$R N A$ extraction. A $90 \mu \mathrm{l}$ inoculum from a culture during exponential growth of the Pss 170 strain in NB medium (Merck, Germany) was added to $70 \mathrm{ml}$ MGY broth medium without $\mathrm{Cu}$ supplementation in a sterile $250 \mathrm{ml}$ Erlenmeyer flask. Bacterial cells were grown in MGY broth medium at $28^{\circ} \mathrm{C}$ and $150 \mathrm{rpm}$ until they reached an optical density at $600 \mathrm{~nm}$ of 0.6 during exponential growth with shaking at $150 \mathrm{rpm}$. At this point, two concentrations of $\mathrm{CuSO}, \mathrm{H}_{2} \mathrm{O}, 0.50$ and $0.75 \mathrm{mM}$, were added to the cultures. Control cultures without the addition of $\mathrm{Cu}$ were also obtained. Bacterial cultures were maintained at $28^{\circ} \mathrm{C}$ and $150 \mathrm{rpm}$. Five ml samples were centrifuged at $5000 \times \mathrm{g}$ at $4^{\circ} \mathrm{C}$ for $15 \mathrm{~min}$ at $2,4,8$ and $12 \mathrm{~h}$ after addition of $\mathrm{Cu}$. Total RNA was extracted immediately using RNX-Plus Solution (SinaClon Co., Iran) as described by the manufacturer. RNA extractions were performed in triplicate. All RNA samples were analysed for quantity using the NanoDrop Nano-200 (Allsheng) and the integrity of the RNA was determined by visualization after gel electrophoresis. Genomic DNA was removed by treatment of RNA samples with RNase-free DNase I (Thermo Fisher Scientific, USA) for $30 \mathrm{~min}$ at $37^{\circ} \mathrm{C}$.

Complementary DNA synthesis and quantitative real-time polymerase chain reaction ( $q R T-P C R$ ). Complementary DNA synthesis was performed as described by the First Strand cDNA Synthesis Kit (Thermo Fisher Scientific). Samples of cDNA obtained from three independent replicates of each treatment were pooled. The pooled cDNA served as a single biological replicate for each treatment condition and used in triplicate
qRT-PCR. It was performed using the RealQPCR $2 \times$ SYBR Green Master Mix (Ampliqon) in a StepOne ${ }^{\mathrm{TM}}$ Real-Time PCR System (Applied Biosystems $(\mathbb{R})$. Genespecific primers for the genes algD, cop $\mathrm{A}, f i \mathrm{C}, \operatorname{hrp} \mathrm{A}$, rpo $\mathrm{D}$, syr $\mathrm{B}$ and tat $\mathrm{C}$ were designated using the program AlleleID, version 6.0 (Premier BioSoft, USA). The qRTPCR primers were designed in order to have a length of about 20 to 25 bases, a G/C content of over $50 \%$, Tm of $60^{\circ} \mathrm{C}$ and the length of the PCR product ranged from 90 to $130 \mathrm{bp}$. The rpoD gene was used as an internal reference as in previous qRT-PCR experiments (Hockett et al., 2013).

Primer sequences are shown in Table 2. For each of the 12 independent pooled cDNA samples, gene expression was measured in three technical replications and non-template control. The mean of these values was used for further analysis.

The PCR reaction mixtures in a total volume of $15 \mu \mathrm{l}$ contained $7.5 \mu \mathrm{l}$ of SYBR Green RT PCR Master Mix, 10 pmol of forward and reverse primers and $5 \mu \mathrm{l}$ of cDNA template. The amplification conditions were as follows: one cycle of initial denaturation at $95^{\circ} \mathrm{C}$ for $2 \mathrm{~min}$, followed by 40 cycles at $95^{\circ} \mathrm{C}$ for $15 \mathrm{~s}$, at $56^{\circ} \mathrm{C}$ for $25 \mathrm{~s}$ and at $72^{\circ} \mathrm{C}$ for $30 \mathrm{~s}$. The specificity of all primer pairs and all amplification reactions was confirmed by single-peak melting curve analysis (a denaturing step at $95^{\circ} \mathrm{C}$ for $15 \mathrm{~s}$, a hybridization step of $1 \mathrm{~min}$ at $70^{\circ} \mathrm{C}$, followed by temperature increases of $0.3^{\circ} \mathrm{C}$ per cycle from $70^{\circ} \mathrm{C}$ to $95^{\circ} \mathrm{C}$ with a $5 \mathrm{~s}$ stop between each step). Gel electrophoresis and melting curve analysis of PCR products showed that very little or no primer dimers were generated. All raw values were normalized to the rpoD gene, which was used as internal reference gene. The relative expression ratios were calculated following the model of Pfaffl (2001), which included an efficiency correction for real-time PCR efficiency of the individual transcripts:

$$
\begin{aligned}
& \text { Ratio }=\left(\mathrm{E}_{\text {target gene }}\right)^{\Delta \mathrm{Ct}} \text { target(control - sample) } / \\
& \left(\mathrm{E}_{\text {reference gene }}\right)^{\Delta \mathrm{Ct}} \text { ref(control - sample) }
\end{aligned}
$$

where $\mathrm{E}$ is the real-time PCR efficiency for a given gene, $\mathrm{Ct}$ - the crossing point of the amplification curve with the threshold, $\Delta \mathrm{Ct}$ - the crossing point

\begin{tabular}{|c|c|c|c|c|c|}
\hline Gene & Function & Primer name & Primer sequence 5' to 3' & Amplicon size & Efficiency \\
\hline $\operatorname{alg} \mathrm{D}$ & Alginate synthesis & $\begin{array}{l}\text { qRTalgDF } \\
\text { qRTalgDR }\end{array}$ & $\begin{array}{l}\text { GATAGTGTGGCGGGTGGCTTT } \\
\text { AAGAACGGCGATCTGGAACTGG }\end{array}$ & $90 \mathrm{bp}$ & $90 \%$ \\
\hline $\operatorname{cop} \mathrm{A}$ & Copper resistance & $\begin{array}{l}\text { qRTcopAF } \\
\text { qRTcopAR }\end{array}$ & $\begin{array}{l}\text { GTCATTGCCGAGCCGTTG } \\
\text { GCGACCTACACCTACCTGATG }\end{array}$ & $110 \mathrm{bp}$ & $90 \%$ \\
\hline$f l i \mathrm{C}$ & Flagellin & $\begin{array}{l}\text { qRTflicF } \\
\text { qRTflicR }\end{array}$ & $\begin{array}{l}\text { ACTCGCAGATCAAAGGTCAG } \\
\text { AGCCAGTTCACGCATACG }\end{array}$ & $125 \mathrm{bp}$ & $92.5 \%$ \\
\hline hrpA & Hrp pilus & $\begin{array}{l}\text { qRThrpAF } \\
\text { qRThrpAR }\end{array}$ & $\begin{array}{l}\text { CGCCGACCGTAATGCTG } \\
\text { GCCGTTCTCTTCGTTCGC }\end{array}$ & $130 \mathrm{bp}$ & $90 \%$ \\
\hline rpoD & Sigma factor 70 & $\begin{array}{l}\text { qRTrpoDF } \\
\text { qRTrpoDR }\end{array}$ & $\begin{array}{l}\text { GCCAGCGACGAAGAAGAC } \\
\text { GCCTTGCGGGTGATTTCC }\end{array}$ & $101 \mathrm{bp}$ & $92.5 \%$ \\
\hline syr B & Syringomycin synthesis & $\begin{array}{l}\text { qRTsyrBF } \\
\text { qRTsyrBR }\end{array}$ & $\begin{array}{l}\text { ACGCTCGGGCTGGTTTGC } \\
\text { CGACCTGATGACCCTGGAGAG }\end{array}$ & $129 \mathrm{bp}$ & $90 \%$ \\
\hline tat $\mathrm{C}$ & Twin-arginin translocase & $\begin{array}{l}\text { qRTtatCF } \\
\text { qRTtatCR }\end{array}$ & $\begin{array}{l}\text { CGATGAATGACGACGACAAG } \\
\text { ATGGTGTGCGGCTGATTC }\end{array}$ & $100 \mathrm{bp}$ & $90 \%$ \\
\hline
\end{tabular}

Table 2. Primers for quantitative real-time polymerase chain reaction (qRT-PCR) used in this study 
difference for an unknown sample versus a control. For each individual gene, the real-time PCR efficiencies were assessed using software LinRegPCR (Rutledge, Stewart, 2008). Amplification efficiencies were determined to be $90 \%$ and $92.5 \%$, and were consistent between gene targets.

Expression levels of genes are presented as the mean of three replicates. For statistical analysis, data were analysed for variance using ANOVA, and the means were compared by Duncan's multiple range test using statistical software MSTAT-C, version 1.42 (Michigan State University, USA). Level of significance for different treatments was determined at $5 \%$ probability $(P<0.05)$.

\section{Results}

Bacterial isolation and identification. A total of 103 Gram-negative strains were isolated. Five fluorescent and aerobic strains were identified as Pss based on the
LOPAT (levan production, oxidase reaction, pectolytic activity on potato slices, arginine dihydrolase activity and hypersensitivity reaction on tobacco leaves) test $(+$, ,,,---+ ) and GATTa (gelatin liquefaction, aesculin hydrolysis, tyrosinase activity and tartrate utilization) test $(+,+,-,-)$. The five strains had been collected from different geographic areas of Iran, including Ajabshir (Pss 26), Marand (Pss 82) and Sepidan (Pss 170, Pss 174 and Pss 176). With the exception of Pss 176, other Pss strains were isolated epiphytically. All five Pss strains produced syringomycin like toxins based on their ability to inhibit mycelial growth of Geotrichum candidum were ice nucleation active and were pathogenic on oneyear-old apricot twigs inducing severe necrotic lesions at injection sites (Table 3 ). Large bacterial populations showing the same colony morphologies were re-isolated from infected tissues and confirmed to be Pss based on biochemical tests and PCR.

Table 3. Pseudomonas syringae pv. syringae (Pss) strains isolated from infected apricot tissues used in this study

\begin{tabular}{|c|c|c|c|c|c|c|c|c|c|c|c|c|c|c|c|c|}
\hline \multirow[t]{2}{*}{ Strains } & \multirow{2}{*}{$\begin{array}{c}\text { Geographical } \\
\text { areas }\end{array}$} & \multirow{2}{*}{$\begin{array}{l}\text { Kind of } \\
\text { isolation }\end{array}$} & \multicolumn{5}{|c|}{$\begin{array}{l}\text { LOPAT } \\
\text { results }\end{array}$} & \multicolumn{4}{|c|}{$\begin{array}{l}\text { GATTa } \\
\text { results }\end{array}$} & \multirow{2}{*}{$\begin{array}{c}\text { Pathogenicity } \\
\text { test }\end{array}$} & \multirow{2}{*}{$\begin{array}{c}\text { Ice } \\
\text { nucleation } \\
\text { activity }\end{array}$} & \multirow{2}{*}{$\begin{array}{l}\text { Syringomycin } \\
\text { production }\end{array}$} & \multirow[t]{2}{*}{$\mathrm{MIC}-\mathrm{Cu}$} & \multirow[t]{2}{*}{$\begin{array}{l}\text { Detection } \\
\text { of } s y r \mathrm{~B}\end{array}$} \\
\hline & & & $\mathrm{L}$ & $\mathrm{O}$ & $\mathrm{P}$ & A & $\mathrm{T}$ & $\mathrm{G}$ & $\mathrm{A}$ & $\mathrm{T}$ & $\mathrm{T}$ & & & & & \\
\hline Pss 26 & Ajabshir & Epiphytic & + & - & - & - & + & + & + & - & - & + & + & + & $0.50 \mathrm{mM}$ & + \\
\hline Pss 82 & Marand & Epiphytic & + & - & - & - & + & + & + & - & - & + & + & + & $0.75 \mathrm{mM}$ & + \\
\hline Pss 170 & Sepidan & Epiphytic & + & - & - & - & + & + & + & - & - & + & + & + & $0.75 \mathrm{mM}$ & + \\
\hline Pss 174 & Sepidan & Epiphytic & + & - & - & - & + & + & + & - & - & + & + & + & $0.50 \mathrm{mM}$ & + \\
\hline Pss 176 & Sepidan & Endophytic & + & - & - & - & + & + & + & - & - & + & + & + & $0.75 \mathrm{mM}$ & + \\
\hline
\end{tabular}

$\mathrm{MIC}-\mathrm{Cu}$ - minimum inhibitory concentration of copper

Copper (Cu) resistance of Pseudomonas syringae pv. syringae (Pss) strains on solid medium. To assess the antimicrobial activity of copper, MIC$\mathrm{Cu}$ was evaluated. The results showed that the lower concentrations $(<0.50 \mathrm{mM})$ of $\mathrm{Cu}$ did not cause any appreciable effect on bacterial growth. However, two strains (Pss 26 and Pss 174) were inhibited by $0.50 \mathrm{mM}$ of Cu and three strains (Pss 82, Pss 170 and Pss 176) were inhibited by $0.75 \mathrm{mM}$ of $\mathrm{Cu}$. No growth was observed for any Pss strains at 1 to $4 \mathrm{mM}$ of $\mathrm{Cu}$.

Growth of Pss 170 at different concentrations of $\boldsymbol{C u}$. The growth curve of the $\mathrm{Cu}$ sensitive Pss 170 strain was determined at two different concentrations $(0.50$ and $0.75 \mathrm{mM}$ ) of $\mathrm{Cu}$ in MGY broth medium compared to a control (without $\mathrm{Cu}$ ). In the absence of $\mathrm{Cu}$, Pss 170 reached the exponential phase $(\mathrm{OD} 600=0.6)$ after $10 \mathrm{~h}$, in the $0.50 \mathrm{mM}$ of $\mathrm{Cu}$, Pss 170 reached the exponential phase $(\mathrm{OD} 600=0.6)$ after $124 \mathrm{~h}$, but in the $0.75 \mathrm{mM}$ of $\mathrm{CuSO}$ the bacteria stayed in lag phase during the entire $196 \mathrm{~h}$ of the experiment (Fig. 1).

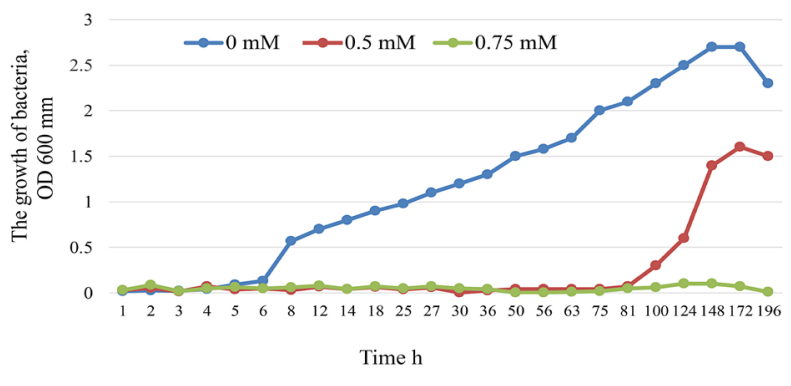

OD - optical density

Figure 1. Growth curve of Pseudomonas syringae pv. syringae 170 strain (Pss 170) in presence of two concentrations $(0.50$ and $0.75 \mathrm{mM})$ of $\mathrm{Cu}$ compared with control (absence of $\mathrm{Cu}$ ) in MGY broth medium

Detection of rpoD, syrB, copA and copB genes in Pss strains. Using rpoD-Fp/rpoD-Rp primers, a 532 bp fragment was amplified from all collected Pss strains (Fig. 2). The presence of the syrB gene using $\mathrm{B} 1 / \mathrm{B} 2$ primers was verified by amplification of a 752 bp fragment in all strains (Fig. 3). The presence of the $\mathrm{Cu}$ resistant genes $\operatorname{cop} \mathrm{A}$ and $\operatorname{cop} \mathrm{B}$ was verified by amplification of $650 \mathrm{bp}$ (Fig. 4) and $506 \mathrm{bp}$ fragments in all Pss strains (Fig. 5) using the designed PsscopAF/R and PsscopBF/R primers, respectively.

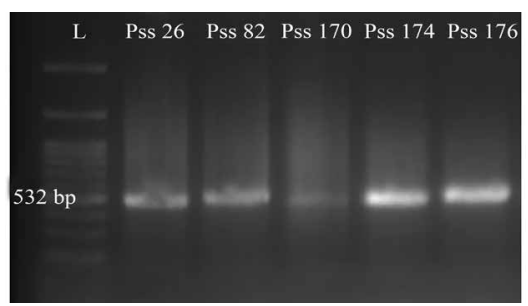

L - 100 bp DNA ladder

Figure 2. Agarose 1\% gel electrophoresis of PCR products of Pseudomonas syringae pv. syringae (Pss) strains using rpoD-Fp/rpoD-Rp primers

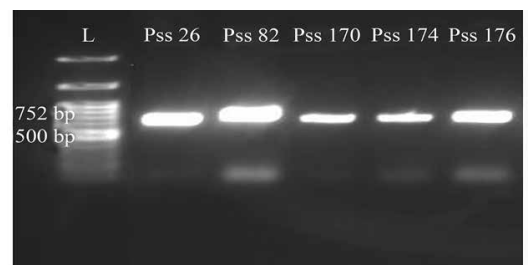

L - 100 bp DNA ladder

Figure 3. Agarose 1\% gel electrophoresis of PCRamplified gene coding syringomycin in Pseudomonas syringae pv. syringae (Pss) strains using B1/B2 primers

Sequence alignment and phylogenetic analysis. Partial nucleotide sequences of the rpoD and cop $\mathrm{A}$ genes obtained from different $\mathrm{Cu}$ sensitive strains of Pss were used for phylogenetic analysis. The average sequence length obtained from amplification was 545 and $620 \mathrm{bp}$ for the rpoD and copA gene, respectively. Edited $r p o \mathrm{D}$ and cop $\mathrm{A}$ gene sequences were aligned to the sequences deposited in NCBI's GenBank database (https://www.ncbi.nlm.nih.gov/). The alignment of the partial nucleotide sequences of the $\mathrm{Cu}$ resistance gene revealed homology of over $96 \%$ for the copA gene among all reference Pss strains in NCBI's GenBank. 


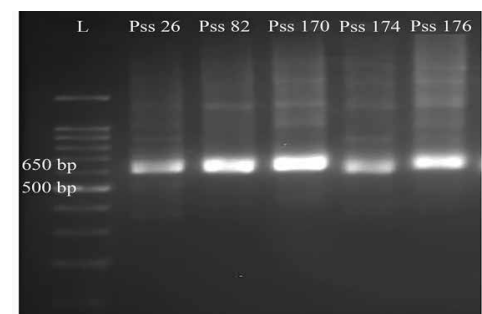

L - 100 bp DNA ladder

Figure 4. Agarose 1\% gel electrophoresis of PCRamplified gene coding syringomycin in Pseudomonas syringae pv. syringae (Pss) strains using PsscopAF/ PsscopAR primers

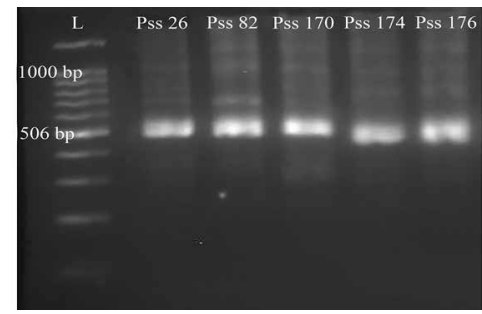

L - 100 bp DNA ladder

Figure 5. Agarose 1\% gel electrophoresis of PCRamplified gene coding syringomycin in Pseudomonas syringae pv. syringae (Pss) strains using PsscopBF/ PsscopBR primers

The best-fit statistical model was determined for each locus based on results from program MrModeltest 2.3. General time reversible with gamma distribution (GTR $+G$ ) model was recommended for both gene fragments. Phylogenetic trees using Bayesian inference method were constructed to evaluate the evolutionary relationships of the five isolated Pss strains with reference strains based on individual sequences of the rpoD (532 nucleotides) and copA (599 nucleotides) genes.

The topology of the copA gene phylogeny was in agreement with the $r p o \mathrm{D}$ gene phylogeny. In the phylogenetic trees based on the rpo $\mathrm{D}$ and copA genes, all Iranian Pss strains clustered into two main groups (Fig. 6). Iranian strains in the main group I were divided into two subgroups. Subgroup I included the Pss 170, Pss 174 and Pss 176 strains collected in Sepidan, and subgroup II included the Pss 26 strain collected in Ajabshir. Group II included the Pss 82 strain collected in Marand area. The Pseudomonas fluorescens R124 strain was used as outgroup. These biomarkers separated strains collected from the apricot orchards in different geographic areas into different groups and subgroups.

Expression of the selected pathogenicity and virulence-related genes. Because little is known about the regulation of the $\mathrm{Cu}$ stress response in Pss strains, the $\mathrm{Cu}$ sensitive Pss 170 strain was exposed to elevated concentrations of $\mathrm{Cu}$ to examine the responses of pathogenicity and virulence-related genes for up to $12 \mathrm{~h}$ using qRT-PCR. The level of relative gene expression was estimated based on the cycle threshold $(\mathrm{Ct})$ values using standard curves. In all cases, the data were normalized relative to the rpoD gene. This housekeeping gene was chosen as an internal control, because previous experiments had shown that its transcript levels were not significantly altered under different conditions. Results are shown in Figure 7.

The algD gene showed a transcript level range of 0.71 to 4.75 in relative expression. Analysis of results showed that there was a statistically significant difference among treatments at the 5\% level (Fig. 3A). In 0.75 and $0.50 \mathrm{mM} \mathrm{Cu}, \operatorname{alg} \mathrm{D}$ gene expression showed up-regulation of 4.75-fold and 3.4-fold compared to the control (without $\mathrm{Cu}$ ) after 4 and $12 \mathrm{~h}$, respectively. Analysis of

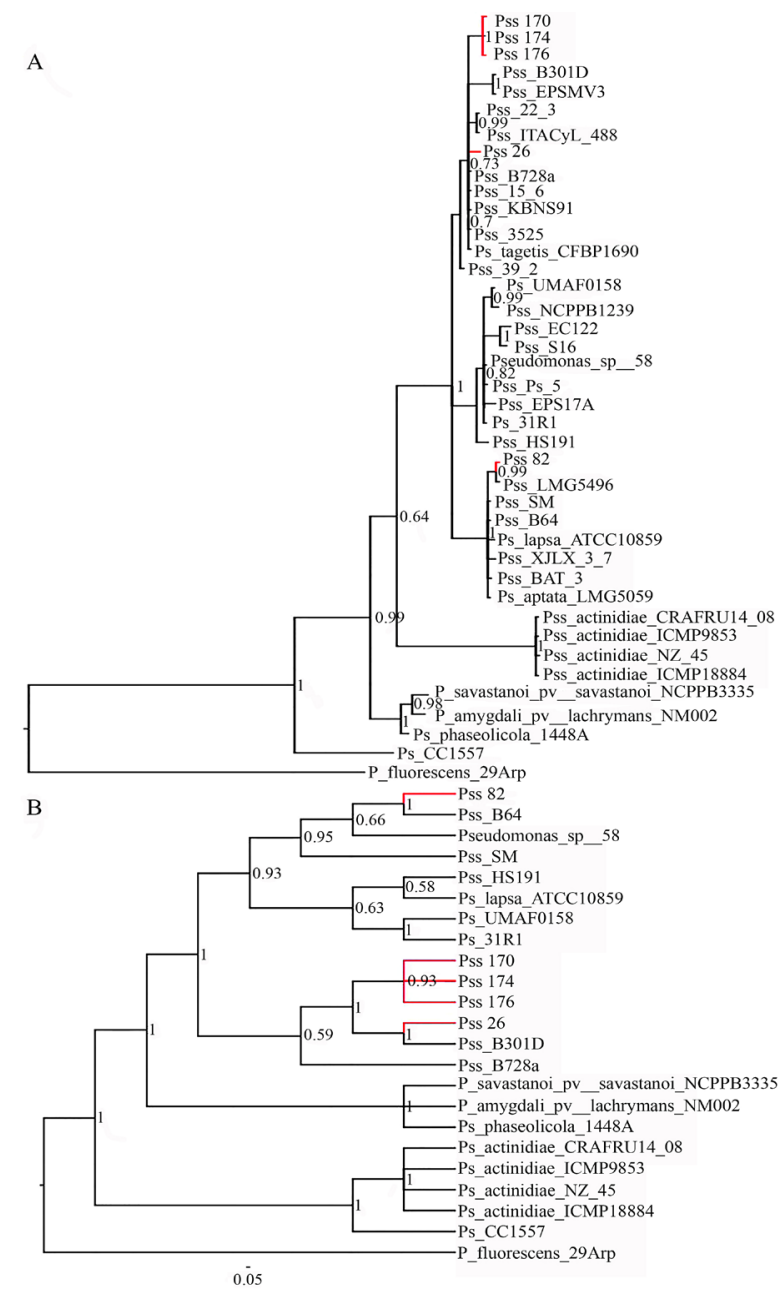

Note. The scale bar represents the average number of substitutions per site, and posterior probability values are shown at the nodes obtained for 100000000 replicates; Iranian strains were shown using pink branches; Pss - Pseudomonas syringae pv. syringae, Ps - Pseudomonas syringae, Pf - Pseudomonas fluorescens.

Figure 6. Phylogenetic trees constructed by Bayesian inference method based on partial sequences of housekeeping RNA polymerase $r p o \mathrm{D}$ (A) and $\mathrm{Cu}$ resistance copA (B) genes among Ps strains using GTR $+\mathrm{G}$ model

relative expression results of the copA gene showed that there was statistical difference among treatments at the 5\% level (Fig. 3B). The copA gene showed up-regulation in 0.75 and $0.50 \mathrm{mM}$ of $\mathrm{Cu}$ after 4 and $12 \mathrm{~h}$ up to 2.68 fold and 2.18-fold compared to the control, respectively. The $f l i \mathrm{C}$ gene showed up-regulation most of the time at both $\mathrm{Cu}$ concentrations compared to control. Statistical analysis of the ratio obtained from relative expression of the $\mathrm{fli}$ gene showed that there was difference among treatments at the 5\% level (Fig. 3C). The highest increase was 1.85 -fold after $12 \mathrm{~h}$ of exposure to $0.75 \mathrm{mM} \mathrm{Cu}$ compared to the control. For the hrpA gene, statistical differences were detected based on the analysis of relative expression among treatments at the 5\% level (Fig. 3D). At both $\mathrm{Cu}$ concentrations, the highest up regulation (1.3-fold and 1.6-fold in 0.50 and $0.75 \mathrm{mM}$, respectively) were detected at 2 and $12 \mathrm{~h}$ compared to the control. The syrB gene showed up-regulation 2.14-fold and 1.6-fold compared to the control in 0.50 and $0.75 \mathrm{mM}$ after 12 and $8 \mathrm{~h}$, respectively, whereby differences were statistically significant among treatments at the 5\% level (Fig. 3E). Analysis of ratios in relative expression of the tatC gene showed that there was a statistically significant difference among treatments at the 5\% level (Fig. 3F). 


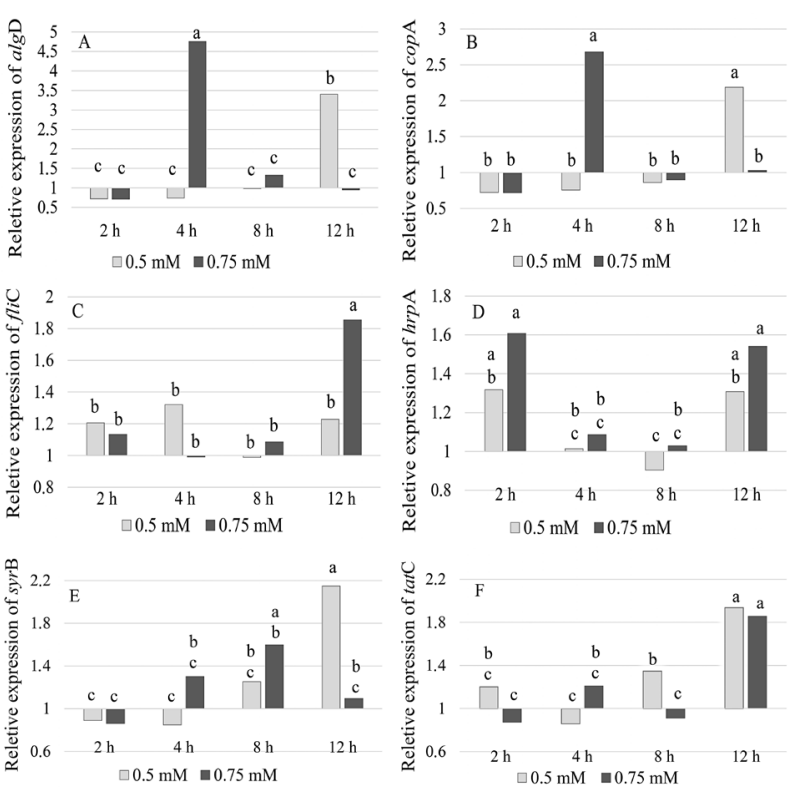

Note. Fold induction relative to the control condition $(0 \mathrm{mM}$ $\mathrm{CuSO}_{4}$ ) is expressed in 2, 4, 8 and $12 \mathrm{~h}$ after addition of the $\mathrm{Cu}$; the relative expression values indicated in the graph are the average of three replicates; ANOVA was calculated using software MSTAT-C and Duncan's multiple range test; $P<0.05$ was considered statistically significant among means.

Figure 7. The relative expression levels of genes $\operatorname{alg} \mathrm{D}$ (A), copA (B), fliC (C), hrpA (D), syrB (E) and tatC (F) were quantified in $\mathrm{Cu}$ sensitive $P$. syringae pv. syringae 170 strain (Pss 170) cells in presence of 0.50 and 0.75 $\mathrm{mM}$ of $\mathrm{CuSO}_{4}$ using qRT-PCR method

The highest up regulation of the tat $\mathrm{C}$ gene was 1.93 -fold and 1.85-fold, which were obtained after $12 \mathrm{~h}$ of $\mathrm{Cu}$ exposure compared to control in 0.50 and $0.75 \mathrm{mM}$ $\mathrm{Cu}$, respectively.

\section{Discussion}

Pseudomonas syringae pv. syringae (Pss), the causal agent of bacterial canker of stone fruit, colonizes trees both epiphytically and endophytically. The epiphytic and endophytic phases play important roles in disease epidemiology: the epiphytic population size of the pathogen is associated with disease incidence and severity, because the epiphytic population of Pss on surfaces of apparently healthy blossoms and leaves provides the inoculum for the endophytic phase of the disease. Four of the five Pss strains collected in this study were isolated epiphytically.

Copper-based antimicrobial compounds are commonly used for controlling bacterial diseases, but there are limitations to their usage: emergence of resistant strains, lack of systemic activity and phytotoxicity. Copper treatments that target epiphytic populations can reduce the size of the epiphytic population and limit the potential increase of the inoculum, thereby reducing disease severity (Wimalajeewa et al., 1991). All Pss strains collected in this study showed ice nucleation activity. The epiphytic phase and the ice nucleation activity followed by injury are both known predisposing factors for canker initiation and development in stone fruit trees (Renick et al., 2008).

All five strains identified here were found to be sensitive to $\mathrm{CuSO}_{4}$ with minimum inhibitory concentrations (MICs) from 0.50 to $0.75 \mathrm{mM}$. The different reactions of Pss strains to MIC-Cu were apparently not related to the geographical origins. In fact, strains isolated from the same geographical area, such as Sepidan, showed different MICs to $\mathrm{Cu}$. The growth rate of Pss 170 strain showed that when the $\mathrm{Cu}$ concentration was increased from 0.50 to $0.75 \mathrm{mM}$ (as MIC), the exponential phase $(\mathrm{OD} 600=0.6)$ was significantly delayed. The MIC determined on solid media may not be the same as the one in liquid media, because some characters, such as agar and $\mathrm{pH}$, can affect metal solubility and availability, respectively (Hartley et al., 1997).

A phylogenetic tree was built based on partial sequences of the $\mathrm{Cu}$ resistance gene copA of the Iranian Pss strains and $P$. syringae reference strains with alignment homology of over $86 \%(E$ value $=0.0)$. In this tree, Iranian strains were placed in two separated groups. Placement of the Iranian strains within the tree correlates with geographic origin so that strains (Pss 170, Pss 174 and Pss 176) isolated from Sepidan cluster in a single subclade with high posterior probability and are separated from strains isolated from Ajabshir (Pss 26) and Marand (Pss 82) areas. The $\mathrm{Cu}$ sensitive Pss 82 strain in group I clustered with high posterior probability with the $\mathrm{Cu}$ resistant Pss B64 reference strain. The strain was isolated from wheat and is ice nucleation active (Hwang et al., 2005). Iranian strains in group II (Pss 170, Pss 174, Pss 176 and Pss 26) are most closely related to two reference strains, Pss B301D and Pss B728a, which were isolated from pear and pea, respectively. Iranian strains in group II were $\mathrm{Cu}$ sensitive (MIC $<0.8 \mathrm{mM} \mathrm{Cu}$ ), ice nucleation active and able to produce syringomycin. Based on previous studies, the two reference strains in this group are $\mathrm{Cu}$ resistant $(\mathrm{MIC}>0.8 \mathrm{mM} \mathrm{Cu}$ ) and are also able to produce syringomycin and are ice nucleation active (Ravindran et al., 2015). Li et al. (2015) hypothesized that the polymorphic $\mathrm{Cu}$ resistance gene copA can be divided into two highly conserved groups encoding for multicopper oxidase and P-type ATPase.

In this study, $P$. syringae strains in the phylogenetic tree based on the alignment of the protein CopA were placed in both, the P-type ATPase and the multicopper oxidase groups. In our study, all Iranian Pss strains clustered with the $P$. syringae refrence strains Pss 64, Pss B728a and Pss 301D encoding for P-type ATPase. CopA is part of the Cu-exporting P-type ATPase IB group of heavy metal transport ATPases (Petersen, Moller, 2000).

The topography of the tree based on partial sequences of the housekeeping gene $r p o \mathrm{D}$ was similar to the $\mathrm{Cu}$ resistance copA gene. In the phylogenic tree based on rpoD, Iranian strains were grouped the same way as in the copA tree. Hwang et al. (2005) reported that the ability of detoxification of $\mathrm{Cu}$ appears to be an ancestral trait in $P$. syringae strains. In our study, the presence of copA gene in all studied Pss strains agreed with detoxification of $\mathrm{Cu}$ being an ancestral trait in P. syringae.

Extracellular polysaccharide (EPS) production, such as that of alginate, has been associated with virulence of Pss strains due to its role in increased epiphytic fitness, facilitation of colonization and/or dissemination in planta, induction of water-soaked lesions on infected leaves, adhesion to plant surfaces, biofilm formation and resistance to toxic molecules and dehydration (Yu et al., 1999; O’Brien et al., 2011). Alginate biosynthesis and secretion genes are conserved in the genomes of some Pss strains (Ravindran et al., 2015). In the present study, the highest expression of algD gene was found at 4 and $12 \mathrm{~h}$ post-exposure to $\mathrm{Cu}$ in 0.75 and $0.50 \mathrm{mM} \mathrm{Cu}$, respectively. Our results are consistent with Kidambi et al. (1995) who reported that $\mathrm{Cu}$-based compounds applied for control of bacterial diseases in plants trigger alginate gene expression and thus increase alginate production in a number of Pss strains upon exposure to $\mathrm{Cu}$ ions.

In previous research, it had been demonstrated that at high concentrations of $\mathrm{Cu}$, defences based on the P-type Cu export ATPase are critical virulence factors in pathogenic bacteria (Argüello et al., 2011). In our study, the expression level of copA showed an over 2-fold upregulation compared to control at $12 \mathrm{~h}$ in $0.50 \mathrm{mM}$ of $\mathrm{Cu}$ and at $4 \mathrm{~h}$ in $0.75 \mathrm{mM} \mathrm{Cu}$. A similar up-regulation of 
the $\mathrm{Cu}$ resistance genes $\operatorname{cop} \mathrm{A}$ and $\operatorname{cop} \mathrm{B}$ was reported in Xanthomonas axonopodis pv. citri (Palmieri et al., 2010). These results can be explained by the role of these genes in bacterial resistance to antimicrobial compounds, which requires a rapid response to increasing $\mathrm{Cu}$ concentrations. The present study is the first to show enhanced expression of virulence-related $h r p \mathrm{~A}, f l \mathrm{C}$ and $s y r \mathrm{~B}$ genes under $\mathrm{Cu}$ stress in any $P$. syringae strain. This is similar to results obtained by Palmieri et al. (2010) for X. axonopodis pv. citri, in which virulence-related $(x c s \mathrm{H}$ and $x c s \mathrm{C})$ genes showed enhanced expression in the presence of $\mathrm{Cu}$.

In different bacterial pathogens, participation of the twin-arginine translocation (TAT) system has been shown in both, assembly and function of the flagellum as well as in secretion of cofactor-bound proteins and much virulence factors (Ochsner et al., 2002). In this study, tat $\mathrm{C}$ gene expression was up-regulated following inoculation with $\mathrm{Cu}$. Up-regulation of the tat $\mathrm{C}$ gene may improve secretion of the $\mathrm{Cu}$ resistance protein CopA since previous studies identified the protein CopA as a substrate of the twin-arginine translocation system in strain DC3000 (Bronstein et al., 2005). Also, in the protein PcoA of $P$. aeruginosa, a CopA orthologue, a TAT signal sequence with twin arginine residues was identified (Vasil et al., 2012). Moreover, Ochsner et al. (2002) showed that $\mathrm{Cu}$ increased inhibition of growth in a $P$. aeruginosa tat $\mathrm{C}$ gene mutant compared to wildtype and the observed increased susceptibility to $\mathrm{Cu}$ was attributed to the protein PcoA.

Based on results of our experiment, the high expression of the genes $\operatorname{alg} \mathrm{D}$ and $\operatorname{cop} \mathrm{A}$ under $\mathrm{Cu}$ stress, their sequence conservation among Pseudomonas strains (Muhammadi, Ahmed, 2007) and essential role in defence against $\mathrm{Cu}$ suggest that novel antimicrobial compounds could be developed to interfere with the function of proteins $\mathrm{AlgD}$ and CopA to increase susceptibility of Pss to $\mathrm{Cu}$.

\section{Conclusions}

1. All collected Pseudomonas syringae pv. syringae (Pss) strains were copper $(\mathrm{Cu})$ sensitive with minimum inhibitory concentration (MIC) less than $0.75 \mathrm{mM}$.

1. In the phylogenic tree based on the $\operatorname{copA}$ gene, all Iranian Pss strains clustered with the Pss reference strains encoding for CopA protein as a part of the $\mathrm{Cu}$-exporting P-type ATPase.

2 . Based on our knowledge, the present study is the first to evaluate the expression of $f l \mathrm{C}, h r p \mathrm{~A}$ and syr B genes under $\mathrm{Cu}$ stress in any Pss strain.

3. Based on gene expression results, we suggest antimicrobials that target $\mathrm{AlgD}$ and CopA proteins could be developed to be used in combination with $\mathrm{Cu}$.

\section{Acknowledgement}

The authors are grateful for financial support from Iran National Science Foundation (INSF) (grant No. 93005043).

Received 13012019

Accepted 17102019

\section{References}

1. Alami M., Luke I., Deitermann S., Eisner G., Koch H. G., Brunner J., Muller M. 2003. Differential interactions between a twin-arginine signal peptide and its translocase in Escherichia coli. Molecular Cell, 12 (4): 937-946. https://doi.org/10.1016/S1097-2765(03)00398-8

2. Argüello J. M., González-Guerrero M., Raimunda D. 2011. Bacterial transition metal P1B-ATPPases: transport mechanism and roles in virulence. Biochemistry, 50 (46) 9940-9949. https://doi.org/10.1021/bi201418k

3. Berge O., Monteil C. L., Bartoli C. Chandeysson C. Guilbaud C., Sands D. C., Morris C. E. 2014. A user's guide to a data base of the diversity of Pseudomonas syringae and its application to classifying strains in this phylogenetic complex. PLoS ONE, 9 (9): e105547. https://doi.org/10.1371/journal.pone.0105547
4. Bronstein P. A., Marrichi M., Cartinhour S., Schneider D. J., DeLisa M. P. 2005. Identification of a twin-arginine translocation system in Pseudomonas syringae pv. tomato DC3000 and its contribution to pathogenicity and fitness. Journal of Bacteriology, 187 (24): 8450-8461. https://doi.org/10.1128/JB.187.24.8450-8461.2005

5. Cazorla F. M., Arrebola E., Sesma A., Pérez-García A., Codina J. C., Murillo J., de Vicente A. 2002. Copper resistance in Pseudomonas syringae strains isolated from mango is encoded mainly by plasmids. Phytopathology, 92 (8): 909916. https://doi.org/10.1094/PHYTO 2002.92.8.909

6. Cervantes C., Gutierrez-Corona F. 1994. Copper resistance mechanisms in bacteria and fungi. FEMS Microbiology Reviews, 14 (2): 121-138. https://doi.org/10.1111/j.1574-6976.1994.tb00083.x

7. Doyle J. J., Doyle J. L. 1990. Isolation of plant DNA from fresh tissue. Focus, 12: 13-15

8. González A. G., Shirokova L. S., Pokrovsky O. S., Emnova E. E., Martínez R. E., Santana-Casiano J. M., González-Dávila M., Pokrovski G. S. 2010. Adsorption of copper on Pseudomonas aureofaciens: protective role of surface exopolysaccharides. Journal of Colloid and Interface Science, 350 (1): 305-314.

https://doi.org/10.1016/j.jcis.2010.06.020

9. Haiko J., Westerlund-Wikström B. 2013. The role of the bacterial flagellum in adhesion and virulence. Biology, 2 (4): 1242-1267. https://doi.org/10.3390/biology2041242

10. Hartley J., Cairney J. W. G., Meharg A. A. 1997. Do ectomycorrhizal fungi exhibit adaptive tolerance to potentially toxic metals in the environment? Plant and Soil, 189 (2): 303-319. https://doi.org/10.1023/A:1004255006170

11. Hockett K. L. Burch A. Y, Lindow S. E. 2013. Thermoregulation of genes mediating motility and plant interactions in Pseudomonas syringae. PLoS ONE, 8 (3): e59850. https://doi.org/10.1371/journal.pone.0059850

12. Hwang M. S. H. Morgan R. L., Sarkar S. F, Wang P. W. Guttman D. S. 2005. Phylogenetic characterization of virulence and resistance phenotypes of Pseudomonas syringae. Applied and Environmental Microbiology, 71 (9): 5182-5191. https://doi.org/10.1128/AEM.71.9.5182-5191.2005

13. Ichinose Y, Taguchi F. Mukaihara T. 2013. Pathogenicity and virulence factors of Pseudomonas syringae. Journal of General Plant Pathology, 79 (5): 285-296. https://doi.org/10.1007/s10327-013-0452-8

14. Kennelly M. M. Cazorla F. M., De Vicente A., Ramos C., Sundin G. W. 2007. Pseudomonas syringae disease of fruit: progress toward understanding and control. Plant Disease, 91 (1): 4-17. https://doi.org/10.1094/PD-91-0004

15. KidambiS.P., Sundin G. W.,PalmerD.A.,Chakrabarty A. M. Bender C. L. 1995. Copper as a signal for alginate synthesis in Pseudomonas syringae pv. syringae. Applied and Environmental Microbiology, 61 (6): 2172-2179.

16. Laue H., Schenk A., Li H., Lambertsen L., Neu T. R. Molin S., Ullrich M. S. 2006. Contribution of alginate and levan production to biofilm formation by Pseudomonas syringae. Microbiology, 152 (10): 2909-2918. https://doi.org/10.1099/mic.0.28875-0

17. Li X. F., Zhu Y. G., Shaban B., Bruxner T. J. C., Bond P. L., Huang L. B. 2015. Assessing the genetic diversity of $\mathrm{Cu}$ resistance in mine tailings through high-throughput recovery of full-length copA genes. Scientific Reports, 5: 13258. https://doi.org/10.1038/srep13258

18. Maddison W. P., Maddison D. R. 2011. Mesquite: a modular system for evolutionary analysis. Version 2.75 . http://www. mesquiteproject.org

19. Mills S. D., Jasalavich C. A., Cooksey D. A. 1993. A twocomponent regulatory system required for copper-inducible expression of the copper resistance operon of Pseudomonas syringae. Journal of Bacteriology, 175 (6): 1656-1664. https://doi.org/10.1128/jb.175.6.1656-1664.1993

20. Mohammadi M., Ghasemi A., Rahimian H. 2001. Phenotypic characterization of Iranian strains of Pseudomonas syringae pv. syringae van Hall, the causal agent of bacterial canker disease of stone fruit trees. Journal of Agricultural Science and Technology, 3 (1): 51-65.

21. Muhammadi A., Ahmed N. 2007. Genetics of bacterial alginate: alginate genes distribution, organization and biosynthesis in bacteria. Current Genomics, 8 (3): 191-202. https://doi.org/10.2174/138920207780833810

22. Najafi Pour Haghighi G., Taghavi S. M. 2014. Discrimination of Pseudomonas syringae pv. syringae isolates from different hosts in Iran using pathogenicity tests and RAPD. International Journal of Agricultural Sciences, 4 (1): 16-27.

23. Nylander J. A. A. 2004. MrModeltest V2.3. Program distributed by the author. Uppsala University, Sweden.

24. O'Brien H. E., Thakur S., Guttman S. D. 2011. Evolution of plant pathogenesis in Pseudomonas syringae: a genomics perspective. Annual Review of Phytopathology, 49: 269-289. https://doi.org/10.1146/annurev-phyto-072910-095242 
25. Ochsner U. A., Snyder A., Vasil A. I., Vasil M. L. 2002. Effects of the twin-arginine translocase on secretion of virulence factors, stress response, and pathogenesis. Proceedings of the National Academy of Sciences of the United States of America, 99 (12): 8312-8317. https://doi.org/10.1073/pnas.082238299

26. Palmieri A. C. B., do Amaral A. M., Homem R. A., Machado M. A. 2010. Differential expression of pathogenicity- and virulence-related genes of Xanthomonas axonopodis pv. citri under copper stress. Genetics and Molecular Biology, $33(2): 348-353$. https://doi.org/10.1590/S1415-47572010005000030

27. Penaloza-Vázquez A., Kidambi S. P., Chakrabarty A. M., Bender C. L. 1997. Characterization of the alginate biosynthetic gene cluster in Pseudomonas syringae. pv. syringae. Journal of Bacteriology, 179 (14): 4464-4472. https://doi.org/10.1128/ib.179.14.4464-4472.1997

28. Petersen C., Moller L. B. 2000. Control of copper homeostasis in Escherichia coli by a P-type ATPase, CopA, and a MerRlike transcriptional activator, CopR. Gene, 261 (2): 289-298. https://doi.org/10.1016/S0378-1119(00)00509-6

29. Pfaffl M. W. 2001. A new mathematical model for relative quantification in real-time RT-PCR. Nucleic Acids Research, 29 (9): e45. https://doi.org/10.1093/nar/29.9.e45

30. Preston G., Huang H. C., He S. Y., Collmer A. 1995. The HrpZ proteins of Pseudomonas syringae pvs. syringae, glycinea, and tomato are encoded by an operon containing Yersinia ysc homologs and elicit the hypersensitive response in tomato but not soybean. Molecular Plant-Microbe Interactions, 8 (5): 717-732. https://doi.org/10.1094/MPMI-8-0717

31. Rademacher C., Masepohl B. 2012. Copper-responsive gene regulation in bacteria. Microbiology (England), 158 (10): 2451-2464. https://doi.org/10.1099/mic.0.058487-0

32. Ravindran A., Jalan N., Yuan J. S., Wang N., Dennis C. Gross D. C. 2015. Comparative genomics of Pseudomonas syringae pv. syringae strains B301D and HS191 and insights into intrapathovar traits associated with plant pathogenesis. Microbiology Open, 4 (4): 553-573. https: //doi.org/10.1002/mbo3.261

33. Renick L. J., Cogal A. G., Sundin G. W. 2008. Phenotypic and genetic analysis of epiphytic Pseudomonas syringae populations from sweet cherry in Michigan. Plant Disease, 92 (3): 372-378. https://doi.org/10.1094/PDIS-92-3-0372

34. Ronquist F., Teslenko M., van der Mark P., Ayres D. L., Darling A., Höhna S., Larget B., Liu L., Suchard M. A., Huelsenbeck J. P. 2012. MrBayes 3.2: efficient Bayesian phylogenetic inference and model choice across a large model space. Systematic Biology, 61 (3): 539-542.

https://doi.org/10.1093/sysbio/sys029

ISSN 1392-3196 / e-ISSN 2335-8947

Zemdirbyste-Agriculture, vol. 107, No. 1 (2020), p. 79-86

DOI $10.13080 / z-a .2020 .107 .011$
35. Rossez Y., Wolfson E. B., Holmes A., Gally D. L., Nicola J., Holden N. J. 2015. Bacterial flagella: twist and stick, or dodge across the kingdoms. PLoS Pathogens, 11 (1): e1004483. https://doi.org/10.1371/journal.ppat.1004483

36. Rutledge R. G., Stewart D. 2008. A kinetic-based sigmoidal model for the polymerase chain reaction and its application to high-capacity absolute quantitative real-time PCR. BMC Biotechnology, 8: 47. https://doi.org/10.1186/1472-6750-8-47

37. Sarkar S. F., Guttman D. S. 2004. The evolution of the core genome of Pseudomonas syringae, a highly clonal, endemic plant pathogen. Applied and Environmental Microbiology, 70 (4): 1999-2012. https://doi.org/10.1128/AEM.70.4.1999-2012.2004

38. Schaad N. W., Jones J. B., Chum W. 2001. Laboratory guide for identification of plant pathogenic bacteria ( $3^{\text {th }}$ ed.).

39. Scheck H. J., Pscheidt J. W., Moore L.W. 1996. Copper and streptomycin resistance in strains of Pseudomonas syringae from Pacific Northwest nurseries. Plant Disease, 80 (9): 1034-1039. https://doi.org/10.1094/PD-80-1034

40. Scholz-Schroeder B. K., Soule J. D., Lu S. E., Grgurina I., Gross D. C. 2001. A physical map of the syringomycin and syringopeptin gene clusters localized to an approximately 145-kb DNA region of Pseudomonas syringae pv. syringae strain B301D. Molecular Plant-Microbe Interaction, 14 (12): 1426-1435. https://doi.org/10.1094/MPMI.2001.14.12.1426

41. Sorensen K. N., Kim K. H., Takemoto J. Y. 1998. PCR detection of cyclic lipodepsinonapeptide-producing Pseudomonas syringae pv. syringae and similarity of strains. Applied and Environmental Microbiology, 64 (1): 226-230. https://doi.org/10.1128/AEM.64.1.226-230.1998

42. Tamura K., Stecher G., Peterson D., Filipski A., Kumar S. 2013. MEGA6: molecular evolutionary genetics analysis version 6.0. Molecular Biology and Evolution, 30 (12): 2725-2729. https://doi.org/10.1093/molbev/mst197

43. Vasil M. L., Tomaras A. P., Pritchard A. E. 2012. Identification and evaluation of twin-arginine translocase inhibitors. Antimicrobial Agents and Chemotherapy, 56 (12): 6223-6234. https://doi.org/10.1128/AAC.01575-12

44. Wimalajeewa D. L. S., Cahill R., Hepworth G. Schneider H. G., Washbourne J. W. 1991. Chemical control of bacterial canker (Pseudomonas syringae pv. syringae) of apricot and cherry in Victoria. Australian Journal of Experimental Agriculture, 31 (5): 705-708. https://doi.org/10.1071/EÀ9910705

45. Yu J. Peñaloza-VázquezA. Chakrabarty A. M.,Bender C. L. 1999. Involvement of the exopolysaccharide alginate in the virulence and epiphytic fitness of Pseudomonas syringae pv. syringae. Molecular Microbiology, 33 (4): 712-720. https://doi.org/10.1046/j.1365-2958.1999.01516.x

\title{
Vario streso ịtaka Pseudomonas syringae pv. syringae patogeniškumo ir virulentiškumo genų raiškai
}

\author{
Y. Vasebi ${ }^{1}$, R. Khakvar ${ }^{1}$, M. M. Faghihi' ${ }^{2}$, B. A. Vinatzer ${ }^{3}$ \\ ${ }^{1}$ Tebrizo universiteto Žemès ūkio fakultetas, Iranas \\ ${ }^{2}$ Irano žemès ūkio tyrimų, mokymo ir konsultavimo organizacijos (AREEO) \\ Hormozgano žemès ūkio ir gamtinių išteklių tyrimų ir mokymo centras \\ ${ }^{3}$ Virdžinijos politechnikos instituto ir valstybinio universiteto \\ Augalų ir aplinkos mokslų technikos mokykla, JAV
}

\section{Santrauka}

Kaulavaisių bakterinis vėžys yra viena žalingiausių abrikosų ligų Irane. Siekiant augalus apsaugoti nuo bakterinių ligu, plačiai naudojami vario junginiai, tačiau patogenai dažnai igauna atsparumą variui. Tyrimo tikslas - ištirti kaulavaisių vėžio sukèlèjo Pseudomonas syringae pv. syringae (Pss) kamienų, išskirtų iš abrikosų medžių Irano Rytu Azerbaidžano provincijoje, genetinę atsparumo variui geno copA įvairovę. Filogeniniai medžiai pagal copA ir rpoD genus yra labai panašūs vienas ị kitą, o tai rodo, kad tarp jų nèra rekombinacijos. Siekiat patikrinti hipotezę, kad Pss kamienuose varis gali indukuoti genus, susijusius su patogeniškumu ir virulentiškumu, taikyta kiekybinè realaus laiko polimerazès grandininè reakcija (qRT-PCR). Siekta ịvertinti genu $\operatorname{alg\mathrm {D}}, \operatorname{cop} \mathrm{A}, f i \mathrm{C}, h r p \mathrm{~A}, \operatorname{syr\mathrm {B}}$ ir $\operatorname{tat} \mathrm{C}$ raišką variui jautriame Pss 170 kamiene veikiant variu. Iš tirtų genų didžiausią raiškos padidejjimą ir atsparumą variui parodè genai $\operatorname{alg} \mathrm{D}$ ir copA, dalyvaujantys alginatų sintezeje - atitinkamai 4,75 ir 2,68 karto, palyginus su kontroliniu variantu be vario. Remiantis tyrimo duomenimis ir algD bei copA genų konservatyvumu Pseudomonas patovaruose, siekiant padidinti apsaugos kontrolès efektyvuma, reikètu sukurti antimikrobines medžiagas, nukreiptas į baltymus AlgD ir CopA, kurios būtų naudojamos kartu su variu.

Reikšminiai žodžiai: algD genas, copA genas, genų ekspresija, kaulavaisių vėžys, realaus laiko PGR. 